\title{
Assessment of heavy metal's in Atlantic sea fish sold in Benin
}

\author{
Elisabeth YEHOUENOU AZEHOUN PAZOU*, Judicaël AZEHOUN PAZOU and \\ Mahoudjro Roméo ADAMOU
}

Laboratoire de Recherche en Biologie Appliquée (LARBA), Département de Génie de l'Environnement, Ecole Polytechnique d'Abomey-Calavi (EPAC), Université d'Abomey-Calavi (UAC), 01 BP 526, Cotonou, Benin.

Private address: 07 Po Box 0265 Cotonou, Republic of Bénin Institution address: Ecole Polytechnique d'Abomey-Calavi (EPAC), Université d'Abomey-Calavi (UAC), 01 BP 2009, Cotonou, Bénin.

*Corresponding author; E-mail: yehouenoue@yahoo.fr; Tel: 00 (229) 95841807

\begin{abstract}
Marine space is constantly threatened by various sources of pollution that may reduce its economic potential and have negative repercussions on human health. This study aims to assess heavy metals contamination of eight fish species and their impact on human health. Heavy metals such as cadmium, lead, copper and zinc were determined by atomic absorption spectrophotometry in fresh, cooked and fried fish. The results found in fresh fish (cadmium: 0.002 to $0.005 \mathrm{mg} / \mathrm{kg}$, lead: 0 to $0.031 \mathrm{mg} / \mathrm{kg}$, copper: 0.0045 to $0.305 \mathrm{mg} / \mathrm{kg}$, zinc: 0.1245 to $0.6195 \mathrm{mg} / \mathrm{kg}$ ), in cooked fish (cadmium: 0.0035 to $0.005 \mathrm{mg} / \mathrm{kg}$, lead: 0 to $0.01 \mathrm{mg} / \mathrm{kg}$, copper: 0 to $0.021 \mathrm{mg} / \mathrm{kg}$, zinc: 0.171 to $0.327 \mathrm{mg} / \mathrm{kg}$ ) and in fried fish (cadmium: $0.004 \mathrm{mg} / \mathrm{kg}$, lead: 0 to $0.007 \mathrm{mg} /$ $\mathrm{kg}$, copper: 0 to $0.016 \mathrm{mg} / \mathrm{kg}$, zinc: 0.0875 to $0.5065 \mathrm{mg} / \mathrm{kg}$ ) showed that heavy metal levels are all below the standard values accepted by FAO / WHO. The consumption of these fish could therefore have no negative effect on the population's health. Both types of cooking have both positive and negative effects on the heavy metal reduction in fish species. Although the concentrations of heavy metals are not worrying, the vigilance of the populations and a variation of the diet are important to guarantee a better health.
\end{abstract}

(C) 2020 International Formulae Group. All rights reserved.

Keywords: Heavy metals, health impact, Atlantic see fish, Cotonou.

\section{INTRODUCTION}

Marine space is an immense reserve of biological resources which constitutes a major part of the world's population diet. However; this space continues to be threatened by various sources of pollution that may reduce its economic potential and have adverse repercussions on human health (Machouri, 1999). Due to human activity thousands of chemical substances end up in the ocean via the atmosphere or continental waters. Some of those substances, such as heavy metals, pesticides and artificial radioelements, are foreign to the marine environment (Nakhlé, 2003).

Among the major consequences of pollution, the chemical pollution has now become a serious concern affecting the hydrosphere. The impact of these substances on the environment is complex, their toxic actions can be direct or indirect on individuals, populations and ecosystems (Devauchelles, 
2002). The consumption of contaminated seafood represents a potential danger to human health.

Benin's coastal area covers $8692 \mathrm{~km}^{2}$ about $7.7 \%$ of the national territory and composed of thirty (30) administrative districts. Along this coastal area there are many ecosystems and infrastructures such as the port, the airport, sales parks for second-hand vehicles, and industries. More than $80 \%$ of Benin's industrial companies such as SOBEBRA, SONICOG, SOBETEX, SOBEPEC, SCB, and CIMBENIN are located in the area between Cotonou and Porto-Novo district (CEDA, 2007). These industrial companies generate liquid waste that is directly dumped into the Atlantic sea.

The occupation of the maritime area by fishermen is the main cause of vegetation cover disappearance and the pollution of beaches by garbage. To this solid household waste are added direct discharges of domestic and industrial waters drained into the sea causing a disturbing pollution for biological resources and for the health of marine products consumers. Thus human health protection and normal functioning of the marine environment requires continuous control of the quality of this ecosystem. With this in mind, this article aims to assess the level of seafood contamination by heavy metals, as well as their impact on human health.

\section{MATERIALS AND METHODS \\ Study area}

This study took place in the Beninese coastal area at Cotonou fishing (Figure 1) port.

\section{Methods \\ Fish sampling}

Early in the morning, fish were sampled directly from marine fishermen. The fish collected were rinsed with distilled water and were immediately kept cold in coolers until they were put to the laboratory for analysis.

\section{Choice of fish species and heavy metals}

Fish choice criteria are: their availability during the study period and their appreciation by the population. The species sampled are: Albula vulpes, Galeoides decadactylus, Scomber scombrus, Brachydeuterus auritus, Sardinella mederensis, Sphyraena barracuda, Trichius lepturus and Cephalopholis taeniops. Ten fish were collected per species. Fish flesh was dissected, freeze-dried and lyophilised, and were ground to fine powder with a mixer for heavy metal's analysis. Heavy metals such as lead and cadmium are chosen in this study because they are the most toxic to humans and the most frequently found in the environment (Viala and Grimaldi, 2005). Copper and zinc are also associated because there are toxic at high thresholds.

\section{Analysis method}

In order to better assess the risks incurred by consumers, it was agreed to analyze the flesh which is the portion consumed by the population. 10 fish per species having approximately the same length and weight were dissected, mixed, weighted and divided into 3 parts: the first was analyzed fresh, the second part was boiled with demineralized water with laboratory flasks and the third was fried with sunflower oil before analysis. They were freeze-dried and lyophilized, and were ground to fine powder. 5 $\mathrm{g}$ of each sample were weighed in a quartz crucible. $5 \mathrm{~g}$ of distilled water in another crucible to serve as blank. The crucibles containing samples and water as blank were put in a programmable oven. Initial temperature was lower than $100^{\circ} \mathrm{C}$. The temperature increased to $450^{\circ} \mathrm{C}$ at a rate of $50^{\circ} \mathrm{C} /$ hour. After this calcinations step, crucibles were removed and allowed to cool down. 1 to $3 \mathrm{ml}$ of water was added and was evaporated in a water bath. $5 \mathrm{ml}$ of hydrochloric acid were added to each crucible and were evaporated. Residue were dissolved in a volume of 10 to $30 \mathrm{ml}$ of nitric acid $0.1 \mathrm{~mol} / \mathrm{L}$. Crucibles were stirred 
thoroughly to dissolve the ashes for 1 to 2 hours then filtered in a $50 \mathrm{ml}$ flask. The resulting solution was then analyzed by atomic spectrophotometer absorption with a Spectr AA110

\section{Statistical analysis}

Heavy metal content data were subjected to a linear mixed effect model to evaluate their variation according to the cooking methods and the species of fish products. The forms of the fish (fresh, cooked and fried) and the species factor were considered fixed and the repetition as random.
The mixed-effect linear model was made possible by the lmer function of the lmerTest package (Kuznetsova, et al., 2017). Adjusted averages were obtained by the lsmeans function of the lsmeans package (Russell, 2016). The ggplot2 package (Wickham, 2016) presented these averages graphically. In order to evaluate the two-to-two correlation between the various heavy metals analyzed, the corrplot function of the corrplot package (Taiyun and Viliam, 2017) was used with the Pearson method. All analyzes and graphs were performed in the R 3.5.1 software.

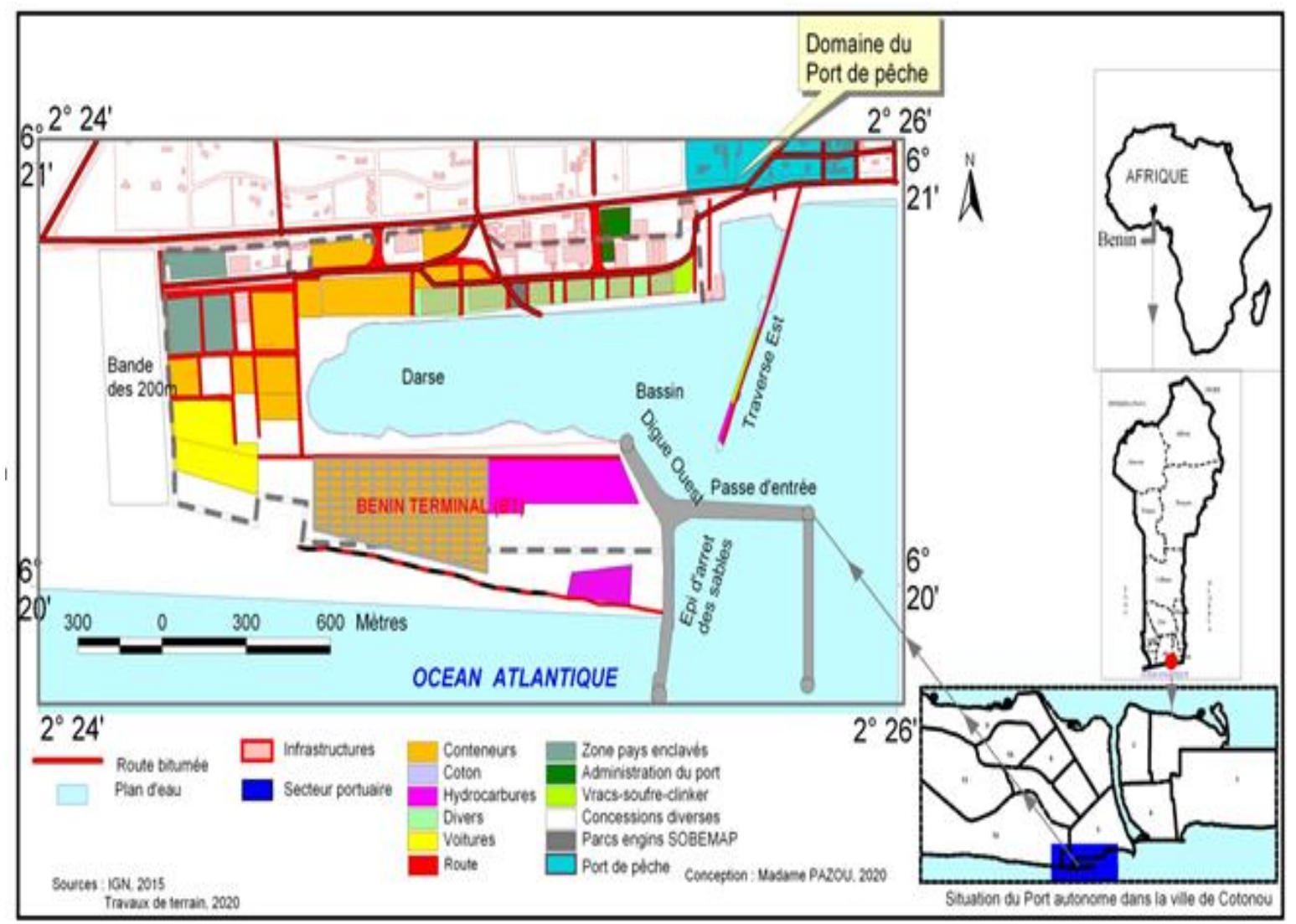

Figure 1: Beninese coastal area at Cotonou fishing. 


\section{RESULTS}

\section{Heavy metal content in fresh fish, cooked and fried}

Heavy metal content in the different species of fish obtained varied from species depending on the cooking methods as shown in Figure 2. Figure 2 shows the presence of cadmium, lead, copper and zinc in almost all species caught (fresh) from the Atlantic Ocean along the Beninese coast. Scomber scombrus is the species that accumulated the most cadmium with $5 \mu \mathrm{g} / \mathrm{kg}$ against Sphyraena barracuda which accumulated the least with $2 \mu \mathrm{g} / \mathrm{kg}$. The species that accumulates the most lead, copper and zinc is Trichius lepturus with $31 \mu \mathrm{g} / \mathrm{kg}$, $305 \mu \mathrm{g} / \mathrm{kg}$ and $619.5 \mu \mathrm{g} / \mathrm{kg}$, respectively. The species that accumulated the least copper and zinc is Brachydeuterus auritus with $4.5 \mu \mathrm{g} / \mathrm{kg}$ and $124.5 \mu \mathrm{g} / \mathrm{kg}$, respectively. None of these concentrations exceeded the FAO / WHO standards for fresh fish $(50 \mu \mathrm{g} \mathrm{Cd} / \mathrm{kg}, 500 \mu \mathrm{g}$ $\mathrm{Pb} / \mathrm{kg}, 3000 \mu \mathrm{g} \mathrm{Cu} / \mathrm{kg}$ and $4000 \mu \mathrm{g} \mathrm{Zn} \mathrm{/} \mathrm{kg)}$

In all the cooked species analyzed, the presence of cadmium and zinc is noted. On the other hand, the presence of lead and copper was recorded only in a few species. In fish, the levels of cadmium, lead, copper and zinc varied between 3.5 and $5 \mu \mathrm{g} / \mathrm{kg}, 0$ and $2 \mu \mathrm{g} / \mathrm{kg}, 0$ and $21 \mu \mathrm{g} / \mathrm{kg}, 171$ and $327 \mu \mathrm{g} / \mathrm{kg}$, respectively. Sphyraena barracuda, Albula vulpes and Sardinella mederensis are the species that accumulated the most cadmium, lead, copper and zinc respectively. None of these concentrations exceeded the FAO / WHO standards for cooked fish. The consumption of these fish would therefore have no negative effect on the population's health.

As for fried fish, the presence of cadmium, lead, copper and zinc has been recorded in most species. Cadmium content is $4 \mu \mathrm{g} / \mathrm{kg}$ in all fish species. For lead, copper and zinc, levels range from 0 to $7 \mu \mathrm{g} / \mathrm{kg}, 0$ to $16 \mu \mathrm{g} / \mathrm{kg}$, and 87.5 to $506.5 \mu \mathrm{g} / \mathrm{kg}$, respectively. Sphyraena barracuda and Trichius lepturus are the species that accumulated the most lead. Scomber scombrus and Trichius lepturus are the species that accumulated the most copper and zinc respectively. None of these concentrations exceeded the FAO / WHO standards for fried fish either. The consumption of these fried fish would therefore have no negative effect on the population's health.

Statistical analysis of these results showed that, with the exception of cadmium, the presence of other heavy metals such as lead, copper and zinc varied significantly depending on the cooking methods and the species. The interaction of these two factors with $\mathrm{p}<0.05$ (Table 1). This variation of heavy metal concentration in fish caught in the Atlantic sea may be due to absorption phenomenon, diffusion and excretion at the time they were caught.

\section{Effects of cooking methods on heavy metal concentration in fish}

Heavy metal determination has focused on three forms of fish namely: fresh, cooked and fried. Table 2 shows the comparison of the presence of heavy metals in the different forms of fish.

From this table it can be seen that the trend in the contents of the different metals varies from one species to another depending on the fish. Indeed, depending on the fish species, it was observed a decrease or increase of cadmium, lead, copper and zinc content from the fresh form to the fried form through the cooked form. It can therefore be deduced that both cooking modes have a positive effect on the reduction of heavy metal levels in fish species. In other fish, the effect was negative. This behavior could be attributed to several parameters such as fish size, oil absorption, water loss and metal evaporation during cooking (Bassey et al., 2014).

Statistical analysis revealed a strong correlation between copper and zinc in fresh and cooked fish. For fried fish, the correlation is strong and positive between lead and zinc (Figure 3). 

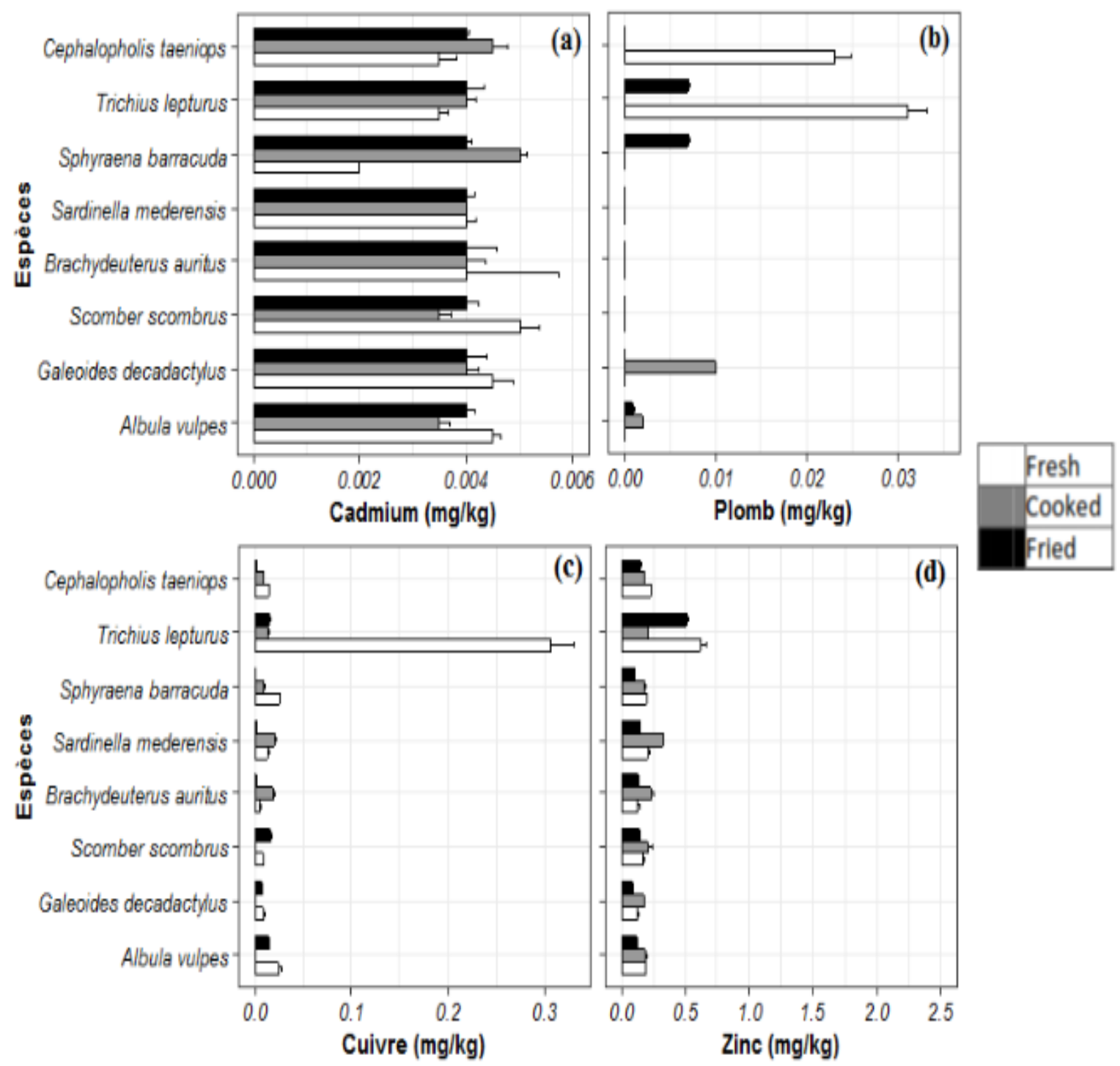

Figure 2: Variation in Heavy Metal Levels in Atlantic Ocean Fishes by Cooking Mode.

Table 1: Results of the linear model on the variation of the contents of heavy metals.

\begin{tabular}{lrrrrrrrrr}
\hline & & \multicolumn{2}{c}{ Cadmium } & \multicolumn{2}{c}{ lead } & \multicolumn{2}{c}{ copper } & \multicolumn{2}{c}{ Zinc } \\
\hline & ddl & F & Prob & F & Prob & F & Prob & F & Prob \\
MC & 2 & 0,91 & 0,411 & 22,33 & $<0,001$ & 15,03 & $<0,001$ & 3,78 & 0,029 \\
E & 9 & 0,40 & 0,929 & 18,06 & $<0,001$ & 102,51 & $<0,001$ & 312,96 & $<0,001$ \\
MC $:$ E & 15 & 1,24 & 0,358 & 17,42 & $<0,001$ & 10,91 & $<0,001$ & 6,51 & $<0,001$ \\
ICC Répétition & & & 0,00 & & 0,00 & & 0,00 & & 0,00 \\
\hline
\end{tabular}

MC: Cooking mode; E: Species; ddl: degree of freedom; F: Fischer statistic; Prob: Probability of significance; ICC: Intra class correlation 
Table 2: Comparison of Heavy Metal Levels in Different Forms of Fish.

\begin{tabular}{|c|c|c|c|c|c|c|c|c|c|c|c|c|}
\hline \multirow{2}{*}{ Fish species } & \multicolumn{3}{|c|}{ Cadmium $(\mu \mathrm{g} / \mathrm{kg})$} & \multicolumn{3}{|c|}{ Lead $(\mu \mathrm{g} / \mathrm{kg})$} & \multicolumn{3}{|c|}{ Copper $(\mu \mathrm{g} / \mathrm{kg})$} & \multicolumn{3}{|c|}{ Zinc $(\mu \mathrm{g} / \mathrm{kg})$} \\
\hline & Fresh & Cooked & Fried & Fresh & Cooked & Fried & Fresh & Cooked & Fried & Fresh & Cooked & Fried \\
\hline Albula vulpes & 4.5 & 3.5 & 4 & $<1$ & 2 & 1 & 25 & $<1$ & 14 & 183 & 19 & 117 \\
\hline $\begin{array}{l}\text { Galeoides } \\
\text { decadactylus }\end{array}$ & 4.5 & 4 & 4 & $<1$ & 0,01 & $<1$ & 9 & $<1$ & 7 & 125.5 & 171 & 87.5 \\
\hline Scomber scombrus & 5 & 3.5 & 4 & $<1$ & $<1$ & $<1$ & 9 & $<1$ & 16 & 167.5 & 212 & 140.5 \\
\hline $\begin{array}{l}\text { Brachydeuterus } \\
\text { auritus }\end{array}$ & 4 & 4 & 4 & $<1$ & $<1$ & $<1$ & 4.5 & 19.5 & 2 & 124.5 & 229 & 128 \\
\hline $\begin{array}{l}\text { Sardinella } \\
\text { mederensis }\end{array}$ & 4 & 4 & 4 & $<1$ & $<1$ & $<1$ & 13.5 & 21 & 2 & 210.5 & 327 & 139 \\
\hline $\begin{array}{l}\text { Sphyraena } \\
\text { barracuda }\end{array}$ & 2 & 5 & 4 & $<1$ & $<1$ & 7 & 25.5 & 9.5 & $<1$ & 193.5 & 171.5 & 1045 \\
\hline Trichius lepturus & 3.5 & 4 & 4 & 31 & $<1$ & 7 & 305 & 13.5 & 15 & 619.5 & 203.5 & 506.5 \\
\hline $\begin{array}{l}\text { Cephalopholis } \\
\text { taeniops }\end{array}$ & 3.5 & 4.5 & 4 & 23 & $<1$ & 1 & 14 & 8.5 & 2 & 224.5 & 170.5 & 148.5 \\
\hline
\end{tabular}

\begin{tabular}{|c|c|c|c|c|c|c|c|c|c|c|}
\hline \multirow[b]{2}{*}{ Cadmium } & Cadmium & Plomb & Cuivre & Zinc & 1 & \multirow[b]{2}{*}{ Cadmium } & Cadmium & Plomb & Cuivre & Zinc \\
\hline & 1 & & -0.37 & -0.44 & & & 1 & & & \\
\hline & Plomb & 1 & 0.48 & 0.33 & 0.4 & & Plomb & 1 & 0.45 & 0.46 \\
\hline (a): Frai & & Cuivre & 1 & 0.85 & 0.2 & (b): $\mathrm{C}$ & uits & Cuivre & 1 & 0.99 \\
\hline & & & Zinc & 1 & 0.8 & & & & Zinc & 1 \\
\hline
\end{tabular}

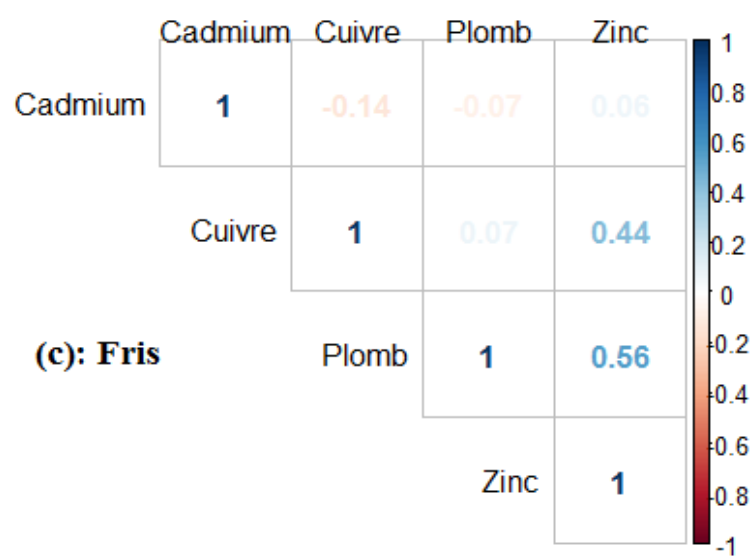

Figure 3: Correlation between heavy metals found in fish in the Atlantic Ocean. 


\section{DISCUSSION}

In this study, heavy metal values obtained in analyzed fresh fish are lower than those obtained by El-Moselhy and al., (2014) in fourteen species of fish collected in the Red Sea in Egypt. They were also below the concentrations of cadmium (1.17- $4.25 \mu \mathrm{g} / \mathrm{g}$ ), lead (3.24-9.17 $\mu \mathrm{g} / \mathrm{g})$, copper (2.3-12.05 $\mu \mathrm{g} /$ g) and zinc (16.79-49.43 $\mu \mathrm{g} / \mathrm{g})$, recorded by Alturiqi and Albedair (2012) in some fish taken from Saudi Arabia markets. However, our results are slightly higher than the concentrations of cadmium $(4.9 \mu \mathrm{g} / \mathrm{kg})$ and lead $(29 \mu \mathrm{g} / \mathrm{kg})$ obtained by Al-Busaidi and al. (2011) in Oman sea fish. The lead levels recorded in Trichius lepturus and Cephalopholis taeniops in this study are higher than those recorded by Tawfik (2013) in the Oreochromis niloticus fish $(0.002 \mu \mathrm{g} / \mathrm{g})$, Mugil cephalus $(0.002 \mu \mathrm{g} / \mathrm{g})$ and Sardinops $\operatorname{sagax}(0.005 \mu \mathrm{g} / \mathrm{g})$. The dissimilarity between these results and those recorded in this study may be due to the difference in many factors such as: feeding habits of fish species, their habitats, their ecological needs, their metabolism, their biology and their physiology (Arellano and al., 1999).

Regarding cooked fish, the results of this work are smaller to those obtained by Huque and al. (2014) in Pampus argenteus boiled fish sampled along Bengal Bay in Bengal. They recorded mean concentrations of $6.03 \mathrm{mg} / \mathrm{kg}, 15.34 \mathrm{mg} / \mathrm{kg}, 3.55 \mathrm{mg} / \mathrm{kg}$ and $24.82 \mathrm{mg} / \mathrm{kg}$ respectively for cadmium, lead, copper and zinc. Obodai and al. (2011) at Ghana obtained in boiled Sarotherodon melanotheron mean concentrations of cadmium $(0.364 \mathrm{mg} / \mathrm{kg})$ and lead $(12.154 \mathrm{mg}$ $/ \mathrm{kg}$ ) which were higher than those obtained for all fish analyzed in this study. However, high levels of lead in food cause kidney failure and damage human liver. Also, fatal ingestions of cadmium exceeding $350 \mathrm{mg} / \mathrm{kg}$ could produce a shock and an acute renal failure (Alturiqi and Albedair, 2012).

Concerning fried fish, results of this study are significantly lower than those obtained by Tawfik (2013) in fried Oreochromis niloticus, Mugil cephalus and Sardinops sagax where he recorded for cadmium respectively $0.021 \mu \mathrm{g} / \mathrm{g}, 0.360 \mu \mathrm{g} /$ $\mathrm{g}$ and $0.821 \mu \mathrm{g} / \mathrm{g}$, for lead respectively 0.011 $\mu \mathrm{g} / \mathrm{g}, 0.011 \mu \mathrm{g} / \mathrm{g}$ and $0.022 \mu \mathrm{g} / \mathrm{g}$, for copper respectively $0.48 \mu \mathrm{g} / \mathrm{g}, 0,89 \mu \mathrm{g} / \mathrm{g}$ and 1.13 $\mu \mathrm{g} / \mathrm{g}$, for zinc respectively $6.45 \mu \mathrm{g} / \mathrm{g}, 8.97 \mu \mathrm{g}$ $/ \mathrm{g}$ and $13.86 \mu \mathrm{g} / \mathrm{g}$. They are also below the concentrations recorded by Devi and Sarojnalini (2012) in Amblypharyngodon mola for copper $(0.023 \mu \mathrm{g} / \mathrm{g})$ and zinc $(0.96 \mu \mathrm{g} / \mathrm{g})$. Copper is an integral part of many enzymes and is needed for hemoglobin synthesis (Huque et al., 2014). Zinc is an essential trace element that is a component of more than 300 enzymes needed to play a role in many biological functions of the human body. However, they become toxic when they exceed maximum limits (Das and Das, 2012).

The results of the cooking method effects on heavy metal levels obtained in fish are similar to those recorded by Ersoy et al. (2006) on Dicentrarchus labrax fish where a positive and negative effect on the heavy metal reduction was recorded according to the cooking methods. On the same fish species, frying and microwave cooking methods showed cadmium and arsenic increase while grilling and boiling methods showed lead decrease. These results are also similar to those obtained by Bassey et al. (2014) in three species of fish from coastal waters of Nigeria. The cooking methods had a significant impact on cadmium concentrations in Cynoglossus senegalensis. In Polydactylus quadratifilis, boiling and frying led to an increase of $100 \%$ of cadmium concentration, while grilling resulted in seven times the cadmium concentration in fresh fish. In addition, cadmium levels in Chrysicthys nigrodigitatus increased. Cadmium increasing during grilling and frying was obviously the result of water loss (Kalogeropoulos et al., 2012). As for lead, its concentration in Polydactylus quadratifilis increased by $5.9 \%$ for boiling, $70.6 \%$ for grilling and $41.2 \%$ for frying. Boiling caused $32.6 \%$ of lead decrease in Chrysicthys nigrodigitatus, while frying and grilling showed $2.2 \%$ and $4.2 \%$ lead increasing respectively. However, the different cooking methods caused $20.8 \%, 22.6 \%$ and $20.8 \%$, 
respectively of lead level decrease in boiled, grilled and fried Cynoglossus senegalensis

\section{Conclusion}

This study evaluated heavy metal contamination in fish caught in southern coastal waters of Benin. It shows that the heavy metal concentrations obtained from the analysis of eight fresh, cooked and fried fish species are all below the standard values accepted by FAO and WHO. The consumption of those fish would therefore have no negative effect on the population's health. However, frequent consumption of a lot of fish per meal can increase the concentration of heavy metals in the consumer's body. Both types of cooking have both positive and negative effects on the reduction of heavy metal levels per fish species. People's vigilance and dietary variation are important to ensure better health even if heavy metal concentrations are not worrying.

\section{COMPETING INTERESTS}

The authors declare that they have no competing interests.

\section{AUTHORS' CONTRIBUTIONS}

This work is the fruit of the contributions of all the authors: EYAP, JAP and MRA.

\section{REFERENCES}

Al-Busaidi M, Yesudhason P, Al-Mughairi S, Al-Rahbi WAK, Al-Harthy KS, AlMazrooei NA, Al-Habsi SH. 2011. Toxic metals in commercial marine fish in Oman with reference to national and international standards. Chemosphere, 85(1): 67-73.

Alturiqi AS, Albedair LA. 2012: Evaluation of some heavy metals in certain fish, meat and meat products in Saudi Arabian markets. The Egyptian Journal of Aquatic Research, 38(1): 45-49.

Arellano JM, Ortiz JB, Capeta Da Silva D, Gonzalez de Canales ML, Sarasquete C, Blasco J. 1999: Levels of copper, zinc, manganese and iron in two fish species from salt marshes of Cadiz Bay (south west Ibrian Peninsula). Bol. Inst. Esp. Oceonogr., 15(1-4): 485-488.

Bassey FI, Oguntunde FC, Iwegbue CMA, Osabor VN, Edem CA. 2014: Effects of processing on the proximate and metal contents in three fish species from Nigerian coastal waters. Food Science \& Nutrition, 2(3) : 272- 281.

CEDA. 2007. Rapport National sur l'Environnement Marin et Côtier du Bénin. Direction Générale de l'Environnement, Ministère de l'Environnement et de la Protection de la Nature, PNUE, 68p.

Das M, Das R. 2012: Need of education and awarenes stowards zinc supplementation: a review. International Journal of Nutrition and Metabolism, 4(3):45-50.

Devauchelles N. 2002: Bilan de santé des organismes et des écosystèmes marins. Quels signaux biologiques mesurer? Ifremer.

http ://archimer.ifremer.fr/doc/00000419 $5 /$

Devi WS, Sarojnalini CH. 2012: Impact of different cooking methods on proximate and mineral composition of amblypharyngodon mola of manipur. International Journal of Advanced Biological Research, 2(4): 712-716.

El-Moselhy KhM, Othman AI, Abd El-Azem H, El-Metwally MEA. 2014. Bioaccumulation of heavy metals in some tissues of fish in the Red Sea, Egypt. Egyptian Journal of Basic and Applied Sciences, 1(2): 97-105.

Ersoy B, Yanar Y, Küçükgülmez A, Çelik M, 2006. Effects of four cooking methods on the heavy metal concentrations of sea bass fillets (Dicentrarchus labrax Linne, 1785). Food Chemistry, 99(4): 748-751.

FAO/WHO, 1989: Evaluation of certain food additives and the contaminants mercury, lead and cadmium, WHO Technical Report Series No. 505.

Felipe de Mendiburu, 2017. Agricolae: Statistical Procedures for Agricultural Research. $\mathrm{R}$ package version 1.2-8. https://CRAN.Rproject.org/package $=$ agricolae 
Huque R, Munshi MK, Khatun A, Islam M, Hossain A, Hossain A, Akter S, Kabir J, Jolly YN, Islam A. 2014. Comparative Study of Raw and Boiled Silver Pomfret Fish from Coastal Area and Retail Market in Relation to Trace Metals and Proximate Composition. International Journal of Food Science, 2014: 1-6.

Kalogeropoulos N, Karavoltsos S, Sakellari A, Avramidou S, Dassenakis N, Scoulla M. 2012. Heavy metals in raw, fried and grilled Mediterranean finfish and shellfish. Food Chem. Toxicol., 50: 37023708.

Kuznetsova A, Brockhoff PB, Christensen RHB. 2017. MerTest Package: Tests in Linear Mixed Effects Models. Journal of statistical Software, 82(13) : 1-26. DOI: 10.18637/jss.v082.i13

Machouri N. 1999. Évaluation de la pollution métallique sur le littoral de la wilaya de Rabat-Salé. Utilisation du mollusque bivalve Mytillus galloprovincialis comme bio-indicateur de la pollution métallique. Thèse de 3è cycle (DESA). UFR Chaire UNESCO «Gestion de l'Environnement et Développement Durable». FLSH. Rabat.

Nakhlé KF. 2003. Le mercure, le cadmium et le plomb dans les eaux littorales libanaises : Apports et suivi au moyen de bioindicateurs quantitatifs (éponges bivalves et gastéropodes). Thèse de doctorat. Spécialité : Interactions Toxiques dans les Ecosystèmes. Université Paris 7 Denis DIDEROT, France, 255p.

Obodai EA, Boamponsem LK, Adokoh CK, Essumang DK, Villawoe BO, Aheto DW, Debrah JS. 2011. Concentrations of heavy metals in two Ghanaian Lagoons. Archives of Applied Science Research, 3(3): 177-187.

Russell VL. 2016. Least-Squares Means: The R Package 1smeans. Journal of statistical Software, 69(1): 1-33. DOI: 10.18637/jss.v 069.i01

Taiyun W, Viliam S. 2017. R package "corrplot": Visualization of a Correlation Matrix (Version 0.84). https://github.com/taiyun/corrplot

Tawfik MS. 2013. Impact of different coocking processes on proximate metals composition of fish and shrimp. Journal of Food Technology, 11(4-6) : 95-102.

Viala A, Grimaldi F. 2005. Ecotoxicologie. In Eléments de Toxicologie (2è Edn), Viala A, Botta A (eds). Tec \& Doc Lavoisier : Paris ; 245-251.

Wickham H. 2016. ggplot2: Elegant Graphics for Data Analysis. Springer-Verlag: New York; 1-253 p. 